\title{
Effects of Long-Term Thyroid Hormone Level Alterations, n-3 Poly- unsaturated Fatty Acid Supplementation and Statin Administration in Rats
}

\section{T. SOUKUP ${ }^{1}$}

${ }^{1}$ Department of Functional Morphology, Institute of Physiology Academy of Sciences of the Czech Republic, Prague, Czech Republic

Received July 9, 2013

Accepted July 25, 2013

\section{Summary}

Thyroid hormones (THs) play multiple roles in the organism and alterations of their levels can result in many pathological changes. Currently, we use hyperthyroid and hypothyroid rats as "models of a diseased organism" and analyze whether n-3 polyunsaturated fatty acids ( $n-3$ PUFA) administration can ameliorate $\mathrm{TH}$-induced pathophysiological changes. We investigate myosin heavy chain composition, calsequestrin levels, changes in cardiac tissue remodeling and cell-to-cell communication, expression of protein kinases, mitochondrial functions, oxidative stress markers and cell death, changes in serum lipid levels, activities of key enzymes of thyroid hormone metabolism, activity of acetylcholine esterase and membrane anisotropy, as well as mobile behavior and thermal sensitivity. Additionally we also mention our pilot experiments dealing with the effect of statin administration on skeletal muscles and sensory functions. As THs and n-3 PUFA possess multiple sites of potential action, we hope that our complex research will contribute to a better understanding of their actions, which can be useful in the treatment of different pathophysiological events including cardiac insufficiency in humans.

\section{Key words}

Thyroid hormones $\bullet$ n-3 polyunsaturated fatty acids (n-3 PUFA) • Statins • Rat muscle proteins $\bullet$ Cardiac remodeling

\section{Corresponding author}

T. Soukup, Institute of Physiology, v.v.i., Academy of Sciences of the Czech Republic, Vídeňská 1083, CZ-14220 Prague, Czech Republic. Fax: $+420-2-4106$ 2488. E-mail: tsoukup@biomed.cas.cz

\section{Introduction}

Thyroid hormones (THs) play an important role in cell growth, development and differentiation and represent one of the major endocrine regulators of cell and tissue metabolic activity. Alterations of their levels in experimental animals can induce different changes including muscle fiber type transitions, alterations of cardiac rhythm, myosin heavy chain (MyHC) and serum lipid level alterations, modification of calcium handling, ion channels, transporters, exchangers and enzyme activities (for review see Soukup and Jirmanová 2000, Hudecova et al. 2004, Kahaly and Dillmann 2005, Bielecka-Dabrowa et al. 2009, Tribulová et al. 2010, Novák and Soukup 2011).

On the other hand, omega n-3 polyunsaturated fatty acids (n-3 PUFA) have been suggested in many clinical trials and animal models (McLennan 2001) to possess multiple effects, including reduction of lipid levels, metabolic effects, direct interactions with cytosolic or membrane bound proteins, alteration of membrane fluidity (after being incorporated into the phospholipid bilayer) or cardiac tissue remodeling and cell-to-cell communications (for review see Den Ruijter et al. 2007, Rupp 2009, Tribulová et al. 2008, 2010, Richardson et al. 2011, Rauch and Senges 2012, von Schacky 2010, 2012), although the data demonstrating improvement remain contradictory. Their effects are usually tested using preparations from fish oil containing a high amount of eicosapentaenoic (EPA) and docosahexaenoic (DHA) n-3 PUFA. These preparations 
are supposed to help in post myocardial infarction states as well in the reduction of hypertriglyceridemia, often as a supplementary treatment to statins.

Statins are drugs used in human therapy to reduce high levels of serum lipids (cholesterol, LDL and triglycerides) and to prevent cardiovascular disease. They are used when dietary regimens and life style changes (body mass reduction and exercise) are not sufficient. On the other hand, it is well known that chronic administration of statins can induce in humans a range of side effects, including skeletal muscle weakness and pain, myopathies or even muscle breakdown (including a life threatening form termed rhabdomyolysis), decreased sensitivity to touch and various neurological problems, such as polyneuropathies or nerve damage resulting in loss of sensitivity in the fingers or toes or the development of neuropathic pain.

The goal of this review is to compare our experiments that have been using hyperthyroid and hypothyroid rats as "a model of a diseased organism" with known literary data. We particularly reviewed whether i) n-3 polyunsaturated fatty acids (n-3 PUFA) administration can ameliorate TH-induced pathophysiological changes such as skeletal muscle protein alterations, cardiac tissue remodeling and cell-tocell communication changes, alterations in expression of protein kinases, mitochondrial functions, oxidative stress markers and cell death, changes in serum lipid levels, in activities of key enzymes of $\mathrm{TH}$ metabolism and acetylcholine esterase or in membrane anisotropy, as well as in mobile behavior and thermal sensitivity, and ii) whether chronic statin administration affects fiber type composition and structure of skeletal muscles, as well as hind paws sensitivity to heat stimuli.

\section{Skeletal muscles}

\section{MyHC isoforms and calcium handling proteins}

Skeletal muscles contain variable proportion of four fiber types, marked slow type 1 and fast 2A, $2 \mathrm{X} / \mathrm{D}$ and 2B fibers (Pette and Staron 2001, Schiaffino 2010). These types can be recognized by immunostaining with specific monoclonal antibodies against individual MyHC isoforms (Fig. 1), using histochemistry, e.g. by myofibrillar ATPase reaction or using RT-PCR to determine the level of MyHC isoform mRNA expression (Schiaffino et al. 1986, Soukup et al. 2002, 2009, Zacharova et al. 2005, Zurmanova et al. 2007, 2008, Smerdu and Soukup 2008, Novák et al. 2010, Zurmanova and Soukup 2013). On the other hand, mammalian heart muscle cells express only two MyHC isoforms, $\alpha$ and $\beta$ (Mahdavi et al. 1982), the latter corresponding to slow type 1 isoform in skeletal muscles and being a product of the same gene. The molecular masses of the rat $\alpha$ and $\beta$ isoforms are both about $223 \mathrm{kDa}$ (Rat Gene Database: http://rgd.mcw.edu/) and their amino acid sequences are $93 \%$ identical (McNally et al. 1989) and their separation using SDS-PAGE is not simple (Arnostova et al. 2011). However, they differ in their ATPase activity and effect on heart contractility, as $\mathrm{MyHC} \alpha$ is a part of a ,fast myosin" with higher ATPase activity and faster contraction, whereas MyHC $\beta$ is contained in a ,slow myosin" with lower ATPase activity and slower contraction (Pope et al. 1980).

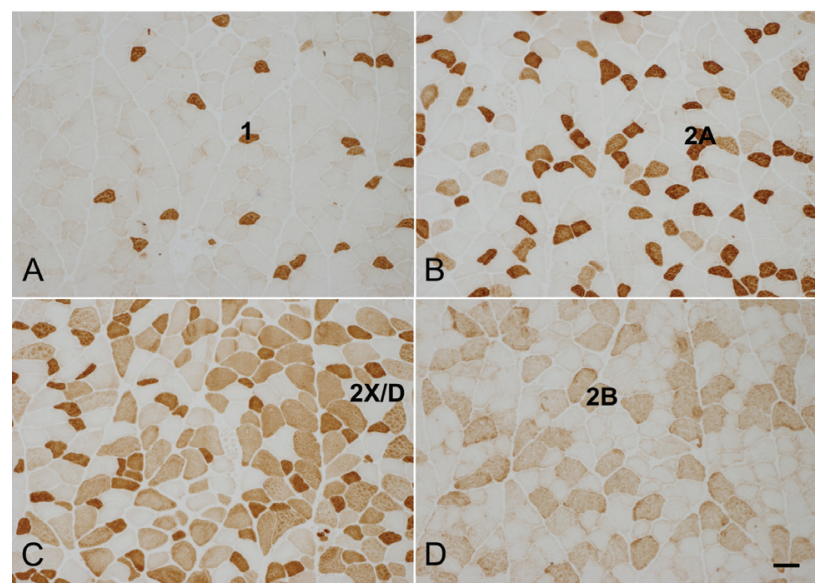

Fig. 1. Examples of cross sections demonstrating immune reactivity of the extensor digitorum longus muscle of adult Lewis euthyroid rats. A: BA-D5 staining slow type 1 fibers, B: SC-71 staining fast $2 \mathrm{~A}$ fibers, C: $\mathrm{BF}-35$ staining all fibers except fast 2X/D and D: BF-F3 staining fast 2B. Bar indicates $100 \mu \mathrm{m}$ (from Soukup et al., Physiol Res 61: 575-586, 2012, with the kind permission of the Journal).

It is generally supposed that the $M y H C$ mRNA levels define the amount of subsequently synthesized $\mathrm{MyHC}$ protein isoforms and decisively contribute to fiber type contractile characteristics (e.g. Schiaffino and Reggiani 1996, Pette 2002, Schiaffino 2010). Skeletal muscles react to $\mathrm{TH}$ alteration by modifying their $\mathrm{MyHC}$ content and fiber type composition (d'Albis and ButlerBrowne 1993, Larsson et al. 1994, Caiozzo et al. 1997, Soukup and Jirmanová 2000, Soukup et al. 2001, 2012, Vadászová et al. 2004, 2006a,b, Vadászová-Soukup and Soukup 2007, Novák and Soukup 2011, Soukup and Zurmanova 2012) and this reaction is different from that occurring in the heart muscle (Dillmann 1990, Tribulová et al. 2010). It is generally supposed that elevated levels 
of THs, as transcriptional factors acting via the thyroid hormone response element (Yen 2001, Fondell 2013), stimulate the expression of fast genes and thus increase expression of fast $\mathrm{MyHC}$ isoforms and number of fast fibers with high mATPase activity (Fig. 2). Furthermore, muscle fiber type characteristics can flexibly react to physiological demands within their given genetic range (Erzen et al. 1996, Snoj-Cvetko et al. 1996a,b). We presented quantitative evidence of corresponding proportions between $m R N A$ level, protein content and fiber type composition in the rat soleus and EDL muscles and suggested that Real Time RT-PCR could be used as a routine method for analyzing muscle composition changes and could thus be advantageous for the analysis of scant biological samples such as muscle biopsies in humans (Zurmanova and Soukup 2013). Alteration of TH status, as well as many other experimental approaches, can lead to mismatch of mRNA, MyHC isoform and fiber type characteristics and may increase the incidence of s.c. mixed fibers expressing more $M y H C$ mRNAs and protein isoforms within a single fiber (Stevens et al. 1999). Hyperthyroid (HT) status significantly increased the number of mixed 2C (1C) fibers in the slow soleus muscle, while the fast EDL muscle was more affected by hypothyroid (HY) status compared to euthyroid (EU) status (Novák and Soukup 2011). Increased numbers of hybrid fibers were also observed after suspension hypokinesia (Asmussen and Soukup 1991, Caiozzo et al. 1997), weightlessness during space flight (Kraemer et al. 2000) or during increased mobility (Asmussen et al. 2003).

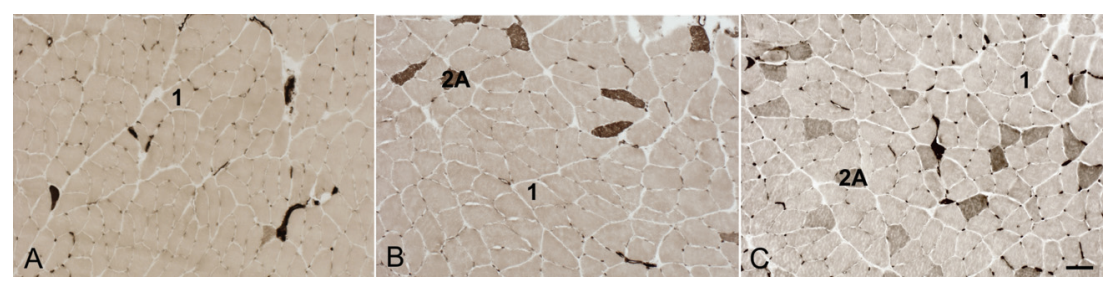

Fig. 2. Examples of cross sections demonstrating alkali-stable mATPase reaction after $\mathrm{pH} 10.3$ pre-incubation of the soleus muscles of adult hypothyroid (A), euthyroid (B) and hyperthyroid (C) Lewis strain rats. The same image was achieved using the SC-71 monoclonal antibody. Slow type I fibers are marked as 1 and fast type $2 \mathrm{~A}$ fibers as $2 \mathrm{~A}$. Note the great difference in the number of darkly stained 2A fibers. Bar indicates $50 \mu \mathrm{m}$ (from Soukup et al., Physiol Res 61: 575-586, 2012, with the kind permission of the Journal).

\section{Calsequestrin expression}

For the physiological change of muscle performance one should expect changes of both contractile and excitation-contraction-coupling (ECC) machinery, namely changes of calcium binding proteins (CaBPs), including calsequestrin (CSQ). CSQ is the most abundant $\mathrm{CaBP}$ of skeletal and cardiac muscle. It maintains free $\mathrm{Ca}^{2+}$ concentrations relatively low, which is important for easier and more efficient transport of released calcium by SERCA pumps. CSQ is a component of the macromolecular complex involved in ECC, the process linking surface membrane depolarization to $\mathrm{Ca}^{2+}$ release from the SR (Berchtold et al. 2000, Dulhunty 2006, Franzini-Armstrong 2009). CSQ is produced as a skeletal (CSQ1) isoform found in fast-twitch and slowtwitch muscles and a cardiac (CSQ2) isoform, considered to be the only transcript present in cardiac and a minor transcript in adult slow-twitch muscle (Beard et al. 2004, Wei et al. 2009). Functional changes of the CSQ complex and its mutations can result in pathology, including impairment of ECC, skeletal muscle myopathies or cardiac arrhythmias (for review see Marks et al. 2002, Tomelleri et al. 2006, for detailed literature survey see
Novák and Soukup 2011). We investigated the effects of altered TH levels on the expression of CSQ1 in relation to simultaneously induced changes in fiber type composition. Both features were analyzed in normal and regenerated fast and slow skeletal muscles and in hearts of EU, HT and HY adult inbred Lewis strain rats. We found that the extent of changes in CSQ1 levels after TH alterations corresponded to the changes of the fiber type composition both in normal and regenerated muscles. This "correlation" was most remarkable after grafting of the soleus muscle into the EDL and vice versa, as the CSQ1 level and fiber type composition corresponded to the level typical for the host muscle and not to that of the graft source (Soukup et al. 2012). The higher TH level thus increased both the level of CSQ1 and the percentages of fast $2 \mathrm{X} / \mathrm{D}$ and $2 \mathrm{~B}$ fibers in the EDL, while HY status lead to opposite changes. This suggests that the observed minor changes in CSQ1 level are probably related to complex fiber type changes occurring during muscle fiber type $\mathrm{TH}$ induced transformation. We observed no significant effect of n-3 PUFA supplementation (unpublished data). 


\section{Pravastatin effect}

We are currently studying two effects of long term statin application known in human pathology, i.e. muscle and sensory perception impairment. We are testing whether muscle structure or fiber type composition as well as MyHC isoform composition, thermal sensitivity and mobile behavior will also change in rats. We use pravastatin, which is one of so-called acid statins (fluvastatin, pravastatin, cerivastatin) that directly inhibit the activity of 3-hydroxy-3-methyl-glutaryl- CoA (coenzyme A) (HMG-CoA), which is a key enzyme in the cholesterol synthesis pathway. Pravastatin can be easily dissolved in water (lactone statins - simvastatin and lovastatin must first be metabolized in the organism and are practically insoluble in water) and can be commercially purchased as a chemical, although it was already used in human therapy. We applied pravastatin beginning from the $4^{\text {th }}$ postnatal week for maximally 21 months. Comparing the life span of rat and man, this corresponds to the administration in man from about the age of 3 to 75 years. The minimal dose was $50 \mu \mathrm{g} / 100 \mathrm{~g}$ at the beginning of the experiments; the maximal dose applied from the $6^{\text {th }}$ month onward was $300 \mu \mathrm{g} / 100 \mathrm{~g}$ of body weight. In man, the minimal dose used is 10 and the maximum $80 \mu \mathrm{g} / 100 \mathrm{~g}$ of body weight. Thus, both the length of administration and dose greatly surmount those used in humans. Nonetheless, our preliminary experiments did not show any significant changes either in the structure of muscle fibers or changes in fiber type or MyHC isoform composition. Also, the thermal sensitivity tested with radiant heat applied to the plantar surface of each hind paw at room temperature (Pospíšilová and Paleček 2006) did not change significantly after chronic pravastatin application. Still, it has been reported that the combined effect of n-3 PUFA and atorvastatin suppresses ventricular fibrillation inducibility in hypertriglyceridemic rat hearts (Bacova et al. 2010).

\section{Heart}

\section{Heart remodeling}

Apart from pathophysiological factors such as hemodynamic overload and diabetes, THs represent the most potent regulator of cardiac MyHC gene expression leading to MyHC transitions and changes of heart contraction (Lompre et al. 1984, Izumo et al. 1986, Ojamaa and Klein 1993, Fletcher and Weetman 1998, Stevenson 2002, Danzi et al. 2008, for review see
Swynghedauw 1986, Morkin 2000, Gupta 2007, Tribulova et al. 2010). We have recently shown that in the left ventricles of EU and HT adult inbred Lewis strain rats, $\mathrm{MyHC} \alpha$ was the predominant isoform, while in $\mathrm{HY}$ rats it was the MyHC $\beta$ isoform (Arnostova et al. 2011). We also showed that the HT status led in Lewis strain rats to cardiac hypertrophy (both absolute and relative), while HY status resulted in heart atrophy. Unfortunately, it is difficult to draw any parallels with the situation in humans, as human hearts contain МyНС $\beta$ as the major isoform. Nonetheless, it is known that chronic exercise induces physiological hypertrophy in humans characterized by the increased expression of $\mathrm{MyHC} \alpha$, while pathological hypertrophy caused by pressure and volume overload leads to the opposite effect (for review see Gupta 2007). Based on the differences in the ATP requirement of the two isoforms, it is accepted that hearts expressing mostly MyHC $\beta$ have a more economical metabolism than those expressing predominantly MyHC $\alpha$. Still, data obtained from studies on transgenic rabbit hearts have indicated that moderate expression of the $\mathrm{MyHC} \alpha$ isoform was advantageous for preserving heart function under stress conditions, suggesting that the benefit to heart function presented by this isoform may outweigh its higher energy demands (James et al. 2005, Gupta 2007). Maybe even more importantly, changes in cardiac MyHC isoforms expression (i.e. shift to $\mathrm{MyHC} \beta$ ) are supposed to be the major cause of heart failure (Gorza et al. 1984, Spann 1984, Miyata et al. 2000, Reiser et al. 2001, Tribulova et al. 2002). Alterations of TH levels thus contribute to various pathological changes, including some of the most life threatening cardiac events, such as atrial and ventricular fibrillations or malignant ventricular arrhythmias (Kahaly and Dillmann 2005, BieleckaDabrowa et al. 2009, Tribulová et al. 2010). Since it was shown that many cardiovascular diseases are associated with a shift between cardiac $\alpha$ and $\beta$ MyHC isoforms, their unequivocal determination by SDS-PAGE is extremely important, especially for human pathology (Arnostova et al. 2011). Malignant cardiac arrhythmias including atrial and ventricular fibrillation represent, as already said, major problems in humans. Certain therapies, such as the administration of statins and n-3 PUFA, are supposed to provide additive antiarrhythmic efficacy by reducing risk factors involved in the development of the arrhythmogenic substrate (myocardial remodeling). Previous experiments suggested that intercellular $\mathrm{Cx} 43$ gap junction channels are involved in the increased susceptibility of the heart to arrhythmias 
caused by increased TH levels and also that expression of $\mathrm{PKC} \varepsilon$, which directly phosphorylates $\mathrm{Cx} 43$, is affected (Tribulová et al. 2002, 2005, Lin et al. 2008, Mitašíková et al. 2009, for review see Dhein 1998, Tribulova et al. 2008,2010 ). Some experiments suggested that n-3 PUFA may exert their protective effect via attenuation of the arrhythmogenic substrate (Mitašíková et al. 2008, Bacova et al. 2011, Radosinska et al. 2011). It was also shown that left ventricle hypertrophy in SHR rats was also associated with "remodeling" of MyHC, which altered susceptibility of the heart to sustained ventricular fibrillation in experimental animals (Tribulova et al. 2002). In our two recent papers (Radosinska et al. 2013, 2014) we found that n-3 PUFA intake significantly reduced cardiovascular risk factors, as they suppressed the incidence of ventricular fibrillation and facilitated sinus rhythm restoration in SHR in early and late stages of hypertension. The antiarrhythmic effects of n-3 PUFA can be attributed to the attenuation of abnormal myocardial Cx43 distribution, expression and phosphorylation, as well as to positive modulation of PKC $\varepsilon$ and $\mathrm{PKC} \delta$ signaling and normalization of $\mathrm{MyHC}$ profiles (Radosinska et al. 2013, 2014). These results support the prophylactic use of $n-3$ PUFA to minimize the risk of lethal arrhythmias in hypertensive individuals. In addition, n-3 PUFA also modify the activity of membrane bound proteins such as the fast sodium channel, the voltage-gated L-type $\mathrm{Ca}^{2+}$ channel, $\mathrm{Na}^{+} / \mathrm{Ca}^{2+}$ exchanger, proteins regulating calcium homeostasis (e.g. SERCA), transporters and membrane receptors or molecular targets such as peroxisome proliferator activated receptors (PPARs) or mitogen activated protein kinase/extracellular signal-related kinase (MEK/ERK) that all can modulate the function of the heart as well as of other organs (e.g. Richardson et al. 2011, Rauch and Senges 2012).

\section{Antioxidant system and cell death}

THs affect the energy metabolism of cardiomyocytes and at physiological concentrations may exert beneficial effects on the heart. Excess of THs can enhance mitochondrial respiration, but also the production of potentially harmful reactive oxygen species (ROS) (Venditti and Meo 2006). THs affect energy metabolism by regulating the gene expression of enzymes involved in oxidative as well as glycolytic metabolism via interaction with $\mathrm{TH}$ receptors (THR). $\mathrm{T}_{3}$-regulated genes also include transcriptional factors such as nuclear respiratory factor 1 (NRF-1) and peroxisome proliferator- activated receptor gamma co-activator $1 \alpha$ (PGC-1 $\alpha$ ), which are critical for mitochondrial metabolism (Weitzel et al. 2011). A stimulatory effect of THs on hypoxia inducible transcriptional factor (HIF1) was also recently described (Moeller et al. 2005), as well as a HIF1 feedback loop controlling THs function via activation of local deiodinase D3 expression (Simonides et al. 2008). There is clear evidence indicating down-regulation of the TH signaling system demonstrated as decrease of THR in the failing heart (for review see Dillmann 2010). The n-3 PUFA that have been shown to build up TH signaling (Souza et al. 2011) may then ameliorate such negative effect. Energy homeostasis of cardiomyocytes and control of apoptosis are also closely connected with the function of proteins associated with outer or inner mitochondrial membranes such as Bcl-2 family proteins (Youle and Astrasser 2008), hexokinase I and II (Miyamoto et al. 2008, Waskova-Arnostova et al. 2013) or the mitochondrial creatine kinase $(\mathrm{mtCK})$. The $\mathrm{mtCK}$ octamer complex is localized in the inter-membrane space between the voltage-dependent anion channel (VDAC) and adenine nucleotide translocase (ANT) (Wallimann et al. 2011). Physiological interaction of the functional $\mathrm{mtCK}$ octamer is dependent on cardiolipin content in the inner membrane (Schlattner et al. 2009) and n-3 PUFAs directly increase the membrane $n-3: n-6$ ratio and cardiolipin content and improve tolerance to ischemia and reperfusion (Pepe 2000). Administration of n-3 PUFA thus could stabilize the mtCK octamer function and support energy homeostasis of cardiomyocytes under altered TH states. New avenues of cardioprotection have been opened by studies of cellular homeostasis, which is regulated by mitochondria, endoplasmic reticulum or expression of cytosolic signaling molecules. Several types of cell death may appear in response to death-inducing stimuli (Fink et al. 2005, Chung et al. 2012, Li et al. 2012). Hypothetically, $\mathrm{TH}$ can also act as a stimulus of cell death, and exploring and attenuating $\mathrm{TH}$ induced autophagy, apoptosis and pyroptosis formation in the damaged heart or other tissues is important for ameliorating the progress of cardiac diseaseas (Chien et al. 2012). Activation of nuclear factor-erythroid-2-related factor 2 (Nrf2) signaling provides cardioprotection, renoprotection and an anti-inflammatory effect, whereas down-regulation or knockout Nrf2 abrogates such protection (Chen et al. 2011, Wu et al. 2011, Chung et al. 2012). It can be assumed that elevated TH level through its receptor overt activation may inhibit nuclear Nrf2 translocation, impair 
Bcl-2/Bcl-xL dependent-mitochondrial function and reduce downstream gene translation products such as HO-1 in the damaged heart. Enhanced Bcl-2/Bcl-xL expression, using Nrf2 activator or n-3 PUFA treatment may countervail $\mathrm{TH}$ induced heart injury.

\section{Serum lipids}

THs are important modulators of lipid metabolism. Generally, hypothyroidism is associated with increased levels of serum triglycerides, cholesterol and LDL cholesterol and vice versa hyperthyroidism is associated with their decreased levels. As regards n-3 PUFAs, they can shift energy substrates away from their storage as triglycerides, suppressing lipogenesis and promoting the utilization of fatty acids as fuel by increasing lipase activity and $\beta$-oxidation in mitochondria and peroxisomes. EPA and DHA are also poor substrates for triglyceride synthesizing enzymes, thus decreasing lipid levels. The hypolipidemic effect of n-3 PUFA is not completely understood, but it seems that it is mainly exerted via the activation of gene expression by upregulation of nuclear transcription factors, such as PPAR $\alpha$ in the liver, which indicates cross-talk between n-3 PUFA and THs (Bordoni et al. 2006, Sugiyama et al. 2008, Souza et al. 2011). Souza et al. (2011) reported that EU Wistar rats maintained on a fish oil diet (n-3 PUFA) exhibited higher liver expression of $\mathrm{TH}$ receptor $\beta 1$ (TR $\beta 1)$. In contrast, in the HY rats, the ability to induce TR $\beta 1$ was lost suggesting the enhancement of THs action following n-3 PUFA supplementation. The recommended dose of n-3 PUFA for humans with established coronary heart disease is $1 \mathrm{~g}$ /day and 3-4 g/day for patients wishing to achieve clinical protection against lipoprotein level elevation (Davidson et al. 2011). In rats, however, even 6-week-supplementation at a higher dose of $0.2 \mathrm{~g} / \mathrm{kg}$ body weight/day, which significantly decreased blood pressure, suppressed inducible ventricular fibrillation, improved myocardial metabolic state, preserved cardiomyocytes and the integrity of their junctions in aged male and female SHR (Mitasikova et al. 2008), had no significant effect on serum postprandial triglyceride, total cholesterol and LDL-cholesterol levels (Rauchová et al. 2013). This could be partially explained by the data of Raederstorff et al. (1991) who showed that the quality and consistency of n-3 PUFA were altered by THs probably due to the competition for desaturases, elongases and acyltransferases between n-3 and n-6 PUFA. Moreover, rats are a rather poor model for testing lipid metabolism because they transport most of their cholesterol in the HDL fraction (Harris 1997) and are relatively hyporesponsive to increasing cholesterol levels (Zhang et al. 2009). Nevertheless, many animal studies have shown that a diet with n-3 PUFA usually lowered plasma triglyceride and total cholesterol levels almost always due to a decrease in HDL cholesterol (Harris 1997).

A good marker of the different thyroid status is mitochondrial glycerol-3-phosphate dehydrogenase (GPDH EC 1.1.99.5.), a flavin-linked enzyme, which is implicated in glycolysis, oxidative phosphorylation and lipid metabolism. It is well known that THs markedly influence GPDH activity in various mammalian organs, such as liver, skeletal muscle or heart (Lee and Lardy 1965, Dümmler et al. 1996). Our chronic experiments confirmed that HT status increased expression and activity of rat liver GPDH, while HY status resulted in opposite changes (Rauchová et al. 2004, 2011).

\section{Metabolism of thyroid hormones}

Multiple biological effects of THs depend on intracellular levels of 3,5,3'-triiodo-L-thyronine $\left(\mathrm{T}_{3}\right)$, which binds to nuclear THRs with the highest affinity. More than $80 \%$ of circulating $\mathrm{T}_{3}$ is generated in peripheral tissues by outer-ring 5 '-deiodination of the pro-hormone thyroxin $\left(\mathrm{T}_{4}\right)$, produced entirely in the thyroid gland. This enzymatic conversion is catalyzed by iodothyronine 5'-deiodinases (IDs) type 1 and 2 (D1 and $\mathrm{D} 2$, respectively). D1 is mainly present in the liver, kidney, thyroid gland and pituitary gland and due to its high specific activity, hepatic D1 is considered the most important source of circulating $\mathrm{T}_{3}$. In turn, its activity is regulated by circulating $\mathrm{T}_{3}$ (Pavelka 2010a). As D1 enzyme activity in white adipose tissue under the conditions of changing adiposity shows pronounced changes (Macek-Jílková et al. 2010), it can be anticipated that supplementing the diet with n-3 PUFA may also influence adipose tissue metabolism and/or accumulation of the tissue in experimental rats by affecting their THs metabolism. Moreover, activities of thyroid peroxidase (TPO) and/or of THs conjugating enzymes (e.g. iodothyronine glucuronyl-transferase, UDP-GT) (Pavelka 2010b, 2012) may be modified by n-3 PUFA supplementation and therefore the rate of biosynthesis and the rate of excretion of metabolized THs can be altered. 


\section{Neurological effects}

There is a close association between THs, brain cholinergic function and AChE activity. Dietary depletion of n-3 PUFA has been shown to adversely affect cholinergic function (Aid et al. 2005) and may contribute to cognitive decline in Alzheimer disease (Astarita et al. 2010). On the other hand, animal studies suggest that higher long-term dietary intake of n-3 PUFA can exert positive effects on various functions of the CNS (Wang et al. 2010) and other tissues, including rat cardiomyocytes (Leifert et al. 2000), apparently due to incorporation of n-3 PUFA into the cellular membrane phospholipid bilayer influencing its fluidity. Our preliminary results, however, failed to demonstrate any significant effect of n-3 PUFA supplementation on AChE activity and membrane fluidity (membrane anisotropy) measured in the cortex, striatum, hippocampus and cerebellum of EU, HT and HY rats (Říčný et al. 2011). Alterations of CNS caused by THs can be reflected by behavioral changes. Experiments measuring activity and response latency in the open field test showed that HT rats reacted with increased activity and shortening of response latency, while HY status yielded opposite results (Redei et al. 2001). Knocking down THR $\alpha$ in mice, mimicking HY status was manifested by decreased activity, learning and recall impairments in the Morris water maze and by increased anxiety/fear behavior in the open field test compared to control C57BL6J mice (Wilcoxon et al. 2007). Our pilot experiments (Petrásek et al. 2011) showed that HT rats are more mobile and HY less mobile than EU rats. The HY rats also spent less time by visiting central parts of the arena (increased thigmotaxis) compared to EU and HT rats. This suggests that behavior of the HY rats was less explorative and more anxious. Alterations of THs are thus involved in behavioral alterations and cognitive deficits resulting in increased anxiety and decreased exploratory behavior. Supplementation with n-3 PUFA, however, did not show any significant effect compared to changes caused by altered thyroid status.

\section{Conclusions}

Polyunsaturated fatty acids (n-3 PUFA) can help in the prevention of adverse cardiac tissue remodeling associated with severe arrhythmias and cell-to-cell communication. Although thyroid hormones (TH) play multiple positive roles in the organism, chronic or prolonged alterations of their levels can result in pathophysiological changes affecting expression of many proteins as well as tissue remodeling. As THs and n-3 PUFA possess multiple sites of potential action, we hope that our complex research will contribute to a better understanding of their actions, which can be useful in the treatment of different pathophysiological events including cardiac insufficiency in humans.

\section{Conflict of Interest}

There is no conflict of interest.

\section{Acknowledgements}

Most of the topics discussed in the review are part of our new grant project proposed by the Department of Functional Morphology (T. Soukup and J. Paleček, skeletal muscles, mobility and thermal perception) in internal collaboration with H. Rauchová and M. Vokurková (serum lipids) and S. Pavelka (metabolism of THs) from the Departments of Experimental hypertension and Radiometry, in external collaboration with J. Ř́čný from the Psychiatric Center, Prague (membrane fluidity, AChE activity) and J. Žurmanová from the Faculty of Sciences, Charles University, Prague (antioxidant system) and in international collaboration with N. Tribulová from the Heart Research Institute, SAS, Bratislava, Slovakia (heart remodeling) and C. T. Chien from the National Taiwan Normal University, Taipei, Taiwan (cell death). The contribution of all collaborators is greatly acknowledged. The author also thanks all the technicians and young colleagues who are the co-authors of publications on which the majority of the presented results are based. These studies were supported by MYORES LSH-CT-2004-511978, GACR 304/08/0256, 305/09/1228 and 304/12/0259 grants, GAAV IAA 601110908, VEGA 2/0046/12, 2/0049/09 grants and MZ0PCP2005, APVV SK-CZ-0027-11, MSM0021620858, MSMT LH12058, MSMT 7AMB 12SK158 grants as well as by Research Project RVO: 67985823 (AV0Z 50110509).

\section{References}

AID S, VANCASSEL S, LINARD A, LAVIALLE M, GUESNET P: Dietary docosahexaenoic acid. J Nutr 135: 10081013, 2005. 
ARNOSTOVA P, JEDELSKY PL, SOUKUP T, ZURMANOVA J: Electrophoretic mobility of cardiac myosin heavy chain isoforms revisited: application of MALDI TOF/TOF analysis. J Biomed Biotechnol 2011: 634253, 2011.

ASMUSSEN G, SOUKUP T: Arrest of developmental conversion of type II to type I fibers after suspension hypokinesia. Histochem J 23: 312-322, 1991.

ASMUSSEN G, SCHMALBRUCH I, SOUKUP T, PETTE D: Contractile properties, fibre types and myosin isoforms of fast and slow muscles of hyperactive Japanese waltzing mice. Exp Neurol 184: 758-766, 2003.

ASTARITA G, JUNG K-M, BERCHTOLD NC, NGUYEN VQ, GILLEN DL, HEAD E, COTMAN CW, PIOMELLI D: Deficient liver biosynthesis of docosahexaenoic acid correlates with cognitive impairment in Alzheimer's disease. PLoS One 5: e12538, 2010.

BACOVA B, RADOSINSKA J, KNEZL V, KOLENOVA L, WEISMANN P, NAVAROVA J, BARANCIK M, MITASIKOVA M, TRIBULOVA N: Omega-3 fatty acids and atorvastatin suppress ventricular fibrillation inducibility in hypertriglyceridemic rat hearts: implication of intracellular coupling protein, connexin-43. J Physiol Pharmacol 61: 717-723, 2010.

BACOVA B, RADOSINSKA J, SOUKUP T, TRIBULOVA N: Effect of omega-3 fatty acids diet on myocardial connexin-43 expression in Lewis rats with altered thyroid status. Physiol Res 60: 25P, 2011.

BIELECKA-DABROVA A, MIKHAILIDIS DP, RYSZ J, BANACH M: The mechanisms of atrial fibrillation in hyperthyroidism. Thyroid Res 2: 1756-6614-2-4, 2009.

BERCHTOLD MW, BRINKMEIER H, MÜNTENER M: Calcium ion in skeletal muscle: its crucial role for muscle function, plasticity, and disease. Physiol Rev 80: 1215-1265, 2000.

BEARD NA, LAVER DR, DULHUNTY AF: Calsequestrin and the calcium release channel of skeletal and cardiac muscle. Prog Biophys Mol Biol 85: 33-69, 2004.

BORDONI A, NUNZIO M, DANESI F, BIAGI PL: Polyunsaturated fatty acids: from diet to binding to PPARs and other nuclear receptors. Genes Nutrition 1: 95-106, 2006.

CAIOZZO VJ, BAKER MJ, MCCUE SA, BALDWIN KM: Single-fiber and whole muscle analyses of MHC isoform plasticity: interaction between T3 and unloading. Am J Physiol 273: C944-C952, 1997.

CHEN DL, CHEN TW, CHIEN CT, LI PC: Intravenous low redox potential saline attenuates FeCl3-induced vascular dysfunction via downregulation of endothelial $\mathrm{H} 2 \mathrm{O} 2$, CX3CL1, intercellular adhesion molecule-1, and p53 expression. Translational Res 157: 306-319, 2011.

CHIEN CT, LEE HM, WU CC, LI PC: Inhibitory effect of botulinum toxin type A on the NANC system in rat respiratory models of neurogenic inflammation. Arch Biochem Biophys 524: 106-113, 2012.

CHUNG SD, LAI TY, CHIEN CT, YU HJ: Activating Nrf-2 signaling depresses unilateral obstruction-evoked mitochondrial stress-related autophagy, apoptosis and pyroptosis in kidney. PLoS One 7: e47299, 2012.

D'ALBIS A, BUTLER-BROWNE G: The hormonal control of myosin isoform expression in skeletal muscle of mammals: a review. Basic Appl Myol 3: 7-16, 1993.

DANZI S, KLEIN S, KLEIN I: Differential regulation of the myosin heavy chain genes alfa and beta in rat atria and ventricles: Role of antisense RNA. Thyroid 18: 761-768, 2008.

DAVIDSON MH, KLING D, MAKI KC: Novel developments in omega-3 fatty acids-based strategies. Curr Opin Lipidol 22: 437-444, 2011.

DEN RUIJTER HM, BERECKI G, OPTHOF T, VERKERK AO, ZOCK PL, CORONEL R: Pro- and antiarrhytmic properties of a diet rich fish oil. Cardiovasc Res 73: 316-325, 2007.

DHEIN S: Gap junctional channels in cardiovascular system: pharmacological and physiological modulation. Trends Pharmacol Sci 9: 229-241, 1998.

DILLMANN WH: Biochemical basis of thyroid hormone action in the heart. Am J Med 88: 626-630, 1990.

DILLMANN WH: Cardiac hypertrophy and thyroid hormone signaling. Heart Fail Rev 15:125-132, 2010.

DÜMMLER K, MÜLLER S, SEITZ HJ: Regulation of adenine nucleotide translocase and glycerol 3-phosphate dehydrogenase expression by thyroid hormones in different rat tissue. Biochem J 317: 913-918, 1996.

DULHUNTY AF: Excitation-contraction coupling from the 1950s into the new millennium. Clin Exp Pharmacol Physiol 33: 763-772, 2006. 
ERZEN I, PRIMC M, JANMOT C, CVETKO E, SKETELJ J, D’ALBIS A: Myosin heavy chain profiles in regenerated fast and slow muscles innervated by the same motor nerve become nearly identical. Histochem J 31: 277-283, 1996.

FONDELL JD: The Mediator complex in thyroid hormone receptor action. Biochim Biophys Acta 1830: 3867-3875, 2013.

FLETCHER AK, WEETMAN AP: Hypertension and hypothyroidism. J Human Hypertens 12: 79-82, 1998.

FINK SL, COOKSON BT: Apoptosis, pyroptosis, and necrosis: mechanistic description of dead and dying eukaryotic cells. Infect Immunol 73: 1907-1916, 2005.

FRANZINI-ARMSTRONG C: Architecture and regulation of the $\mathrm{Ca}^{2+}$ delivery system in muscle cells. Appl Physiol Nutr Metab 34: 323-327, 2009.

GORZA L, MERCADIER JJ, SCHWARTZ K, THORNELL LE, SARTORE S, SCHIAFFINO S: Myosin types in the human heart: an immunofluorescence study of normal and hypertrophied atrial and ventricular myocardium. Circ Res 54: 694-702, 1984.

GUPTA MP: Factors controlling cardiac myosin-isoform shift during hypertrophy and heart failure. J Mol Cell Cardiol 43: 388-403, 2007.

HARRIS WS: n-3 Fatty acids and serum lipoproteins: animal studies. Am J Clin Nutr 65: 1611S-1616S, 1997.

HUDECOVÁ S, VADÁSZOVÁ A, SOUKUP T, KRIŽANOVÁ O: Effect of thyroid hormones on the gene expression of calcium transport systems in rat muscle. Life Sci 75: 923-931, 2004.

IZUMO S, NADAL-GINARD B, MAHDAVI V: All members of the MHC multigene family respond to thyroid hormone in a highly tissue-specific manner. Science 231: 597-600, 1986.

JAMES J, MARTIN L, KRENZ M, QUATMAN C, JONES F, KLEVITSKY R: Forced expression of alpha-myosin heavy chain in the rabbit ventricle results in cardioprotection under cardiomyopathic conditions. Circulation 111: 2339-2346, 2005.

KAHALY GJ, DILLMANN WH: Thyroid hormone action in the heart. Endocr Rev 26: 704-728, 2005.

KRAEMER WJ, STARON RS, GORDON SE, VOLEK JS, KOZIRIS LP, DUNCAN ND, NINDL BC, GÓMEZ AL, MARX JO, FRY AC, MURRAY JD: The effects of 10 days of spaceflight on the shuttle Endeavor on predominantly fast-twitch muscles in the rat. Histochem Cell Biol 114: 349-355, 2000.

LARSSON L, LI X, TERESI A, SALVIATI G: Effects of thyroid hormone on fast- and slow-twitch skeletal muscles in young and old rats. J Physiol Lond 481: 149-161, 1994.

LEE YP, LARDY HA: Influence of thyroid hormones on L- $\alpha$-glycerophosphate dehydrogenase and other dehydrogenases in various organs of the rat. J Biol Chem 240: 1427-1436, 1965.

LEIFERT WR, JAHANGIRI A, MCMURCHIE EJ: Membrane fluidity changes are associated with antiarrhytmic effects of docosahexaenoic acid in adult rat cardiomyocytes. J Nutr Biochem 11: 38-44, 2000.

LI PC, YANG CC, HSU SP, CHIEN CT: Repetitive progressive thermal preconditioning hinders thrombosis by reinforcing phosphatidylinositol 3-kinase/Akt-dependent heat-shock protein/endothelial nitric oxide synthase signaling. J Vasc Surg 56: 159-170, 2012.

LIN H, MITASIKOVA M, DLUGOSOVA K, OKRUHLICOVA L, IMANAGA I, OGAWA K: Thyroid hormones suppress epsilon-PKC signaling, down-regulate connexin-43 and increase lethal arrhythmia susceptibility in non-diabetic and diabetic rat hearts. J Physiol Pharmacol 59: 271-285, 2008.

LOMPRE AM, NADAL-GINARD B, MAHDAVI V: Expression of the cardiac ventricular alpha- and beta-myosin heavy chain genes is developmentally and hormonally regulated. J Biol Chem 259: 6437-6446, 1984.

MACEK-JÍLKOVÁ Z, PAVELKA S, FLACHS P, HENSLER M, KUS V, KOPECKÝ J: Modulation of Type I iodothyronine 5'-deiodinase activity in white adipose tissue by nutrition: possible involvement of leptin. Physiol Res 59: 561-569, 2010.

MAHDAVI V, PERIASAMY M, NADAL-GINARD B: Molecular characterization of two myosin heavy chain genes in the adult heart. Nature 297: 659-664, 1982.

MARKS AR, PRIORI S, MEMMI M, KONTULA K, LAITINEN PJ: Involvement of the cardiac ryanodine receptor/calcium release channel in catecholaminergic polymorphic ventricular tachycardia. $J$ Cell Physiol 190: $1-6,2002$. 
MCLENNAN PL: Myocardial membrane fatty acids and the antiarrhytmic actions of dietary fish oil in animal models. Lipids 36: S111-S114, 2001.

MCNALLY EM, KRAFT R, BRAVO-ZEHNDER M, TAYLOR DA, LEINWAND LA: Full-length rat alpha and beta myosin heavy chain sequences. Comparison suggests a molecular basis for functional differences. $J$ Mol Biol 210: 665-671, 1989.

MITASIKOVA M, SMIDOVA S, MACSALIOVA A, KNEZL V, DLUGOSOVA K, OKRUHLICOVA L, WEISMANN P, TRIBULOVA N: Aged male and female spontaneously hypertensive rats benefit from n-3 polyunsaturated fatty acids supplementation. Physiol Res 57: S39-S48, 2008.

MITASIKOVA M, LIN H, SOUKUP T, IMANAGA I, TRIBULOVA N: Diabetes and thyroid hormones affect connexin-43 and PKC- $\varepsilon$ expression in rat heart atria. Physiol Res 58: 211-217, 2009.

MIYAMOTO S, MURPHY AN, BROWN JH: Akt mediates mitochondrial protection in cardiomyocytes through phosphorylation of mitochondrial hexokinase-II. Cell Death Differ 15: 521-529, 2008.

MIYATA S, MINOBE W, BRISTOW MR, LEINWAND LA: Myosin heavy chain isoform expression in the failing and nonfailing human heart. Circ Res 86: 386-390, 2000.

MOELLER LC, DUMITRESCU AM, WALKER RL, MELTZER PS, REFETOFF S: Thyroid hormone responsive genes in cultured human fibroblasts. $J$ Clin Endocrinol Metab 90: 936-943, 2005.

MORKIN E: Control of cardiac myosin heavy chain gene expression. Microsc Res Tech 50: 522-531, 2000.

NOVÁK P, ZACHAROVA G, SOUKUP T: Individual, age and sex differences in fiber type composition of slow and fast muscles of adult Lewis strain rats. Comparison with other rat strains. Physiol Res 59: 783-801, 2010.

NOVÁK P, SOUKUP T: Calsequestrin distribution, structure and function, its role in normal and pathological situations and the effect of thyroid hormones. Physiol Res 60: 439-452, 2011.

OJAMAA K, KLEIN I: In vivo regulation of recombinant cardiac myosin heavy chain gene expression by thyroid hormone. Endocrinology 132: 1002-1006, 1993.

PAVELKA S: Radiometric enzyme assays: development of methods for extremely sensitive determination of types 1, 2 and 3 iodothyronine deiodinase enzyme activities. J Radioanal Nucl Chem 286: 861-865, 2010a.

PAVELKA S: ${ }^{125}$ I-labelled iodothyronines: useful tools for studies of effects of an antidepressant drug fluoxetine in the rat. J Radioanal Nucl Chem 286: 867-871, 2010b.

PAVELKA S: Use of ${ }^{82} \mathrm{Br}$ and ${ }^{131} \mathrm{I}$ radionuclides in studies of goitrogenic effects of exogenous bromide. $J$ Radioanal Nucl Chem 291: 379-383, 2012.

PEPE S: Mitochondrial function in ischaemia and reperfusion of the ageing heart. Clin Exp Pharmacol Physiol 27: 745-750, 2000.

PETTE D: The adaptive potential of skeletal muscle fibers. Can J Appl Physiol 27: 423-448, 2002.

PETTE D, STARON R S: Transitions of muscle fiber phenotypic profiles. Histochem Cell Biol 115: 359-372, 2001.

PETRÁSEK T, KOPECKÁ K, ZACHAŘOVÁ G, PALEČEK J, TRIBULOVÁ N, SOUKUP T: Effect of thyroid status alteration and red palm oil supplementation on motor activity and thermal sensitivity of adult rats. $48^{\text {th }}$ Lojda Symposium on Histochemistry, Prague, Sept. 4-7, 2011.

POPE B, HOH JFY, WEEDS A: The ATPase activities of rat cardiac myosin isoenzymes. FEBS Letters 118: 205-208, 1980.

POSPÍŚILOVÁ E, PALEČEK J: Post-operative pain behavior in rats is reduced after single high-concentration capsaicin application. Pain 125: 233-243, 2006.

RADOSINSKA J, BACOVA B, BERNATOVA I, NAVAROVA J, ZHUKOVSKA A, SHYSH A, OKRUHLICOVA L, TRIBULOVA N: Myocardial NOS activity and connexin-43 expression in untreated and omega-3 fatty acids-treated spontaneously hypertensive and hereditary hypertriglyceridemic rats. Mol Cell Biochem 347: 163-173, 2011.

RADOSINSKA J, BACOVA B, KNEZL V, BENOVA T, ZURMANOVA J, SOUKUP T, ARNOSTOVA P, SLEZAK J, GONCALVESOVA E, TRIBULOVA N: Dietary omega-3 fatty acids attenuate myocardial arrhythmogenic factors and propensity of the heart to lethal arrhythmias in a rodent model of human essential hypertension. J Hypertens 31: 1876-1885, 2013. 
RADOSINSKA J, BACOVA B, VINCZENCZOVA C, BENOVA T, KNEZL V, ZURMANOVA J, SOUKUP T, GONCALVESOVA E, SLEZAK J, TRIBULOVA N: Maladaptive myocardial responses to hypertension are attenuated by omega-3 fatty acids and red palm oil intake. In: Adaptation Biology and Medicine: New Developments. LM POPESCU, AR HARGENS, PK SINGAL (eds), Narosa Publishing House, New Delhi, Vol. 7, 2014 (in press).

RAEDERSTORFF D, MEIER CA, MOSER U, WALTER P: Hypothyroidism and tyroxin substitution affect the n-3 fatty acid composition of rat liver mitochondria. Lipids 26: 781-787, 1991.

RAUCH B, SENGES J: The effects of supplementation with omega-3 polyunsaturated fatty acids on cardiac rhythm: anti-arrhythmic, pro-arrhythmic, both or neither? It depends... Front Physiol 3: Article 57, 2012.

RAUCHOVÁ H, ZACHAŘOVÁ G, SOUKUP T: Influence of chronically altered thyroid status on the activity of liver mitochondrial glycerol-3-phosphate dehydrogenase in female inbred Lewis rats. Horm Metab Res 36: 286-290, 2004.

RAUCHOVÁ H, MRÁČEK T, NOVÁK P, VOKURKOVÁ M, SOUKUP T: Glycerol-3-phosphate dehydrogenase expression and oxygen consumption in liver mitochondria of female and male rats with chronic alteration of the thyroid status. Horm Metab Res 43: 43-47, 2011.

RAUCHOVÁ H, VOKURKOVÁ M, PAVELKA S, BEHULIAK M, TRIBULOVÁ N, SOUKUP T: N-3 polyunsaturated fatty acids supplementation does not affect changes of lipid metabolism induced in rats by altered thyroid status. Horm Metab Res 45: 507-512, 2013.

REDEI EE, SOLBERG LC, KLUCZYNSKI JM, PARE WP: Paradoxical hormonal and behavioral responses to hypothyroid and hyperthyroid states in the Wistar-Kyoto rat. Neuropsychopharmacol 24: 632-639, 2001.

REISER PJ, PORTMAN MA, NING XH, SCHOMISCH MORAVEC C: Human cardiac myosin heavy chain isoforms in fetal and failing adult atria and ventricles. Am J Physiol Heart Circ Physiol 280: H1814-H1820, 2001.

RICHARDSON ES, IAIZZO PA, XIAO YF: Electrophysiological mechanisms of the antiarrhythmic effects of omega3 fatty acids. $J$ Cardiovasc Trans Res 4: 42-52, 2011.

RUPP H: Omacor (prescription omega-3-acid ethyl esters 90): From severe rhythm disorders to hypertriglyceridemia. Adv Ther 26: 675-690, 2009.

ŘÍČNÝ J, ŘIIPOVÁ D, TRIBULOVÁ N, SOUKUP T: Acetylcholinesterase activity and membrane fluidity in rats with altered thyroid status and/or omega-3 unsaturated fatty acid dietary supplementation. WCBR, Prague, 2011.

SCHIAFFINO S: Fibre types in skeletal muscle: a personal account. Acta Physiol (Oxf) 199: 451-463, 2010.

SCHIAFFINO S, REGGIANI C: Molecular diversity of myofibrillar proteins: gene regulation and functional significance. Physiol Rev 76: 371-423, 1996.

SCHIAFFINO S, SAGGIN L, VIEL A, AUSONI S, SARTORE S, GORZA L: Muscle fiber types identified by monoclonal antibodies to myosin heavy chains. In: Biochemical Aspects of Physical Exercise. BENZI G, PACKER L, SILIPRANDI N (eds), Elsevier, Amsterdam, 1986, pp 27-34.

SCHLATTNER U, TOKARSKA-SCHLATTNER M, RAMIREZ S, BRUCKNER A, KAY L, POLGE C, EPAND RF, LEE RM, LACOMBE ML, EPAND RM: Mitochondrial kinases and their molecular interaction with cardiolipin. Biochim Biophys Acta 1788: 2032-2047, 2009.

SIMONIDES WS, MULCAHEY MA, REDOUT EM, MULLER A, ZUIDWIJK MJ, VISSER TJ, WASSEN FW, CRESCENZI A, DA-SILVA WS, HARNEY J, ENGEL FB, OBREGON MJ, LARSEN PR, BIANCO AC, HUANG SA: Hypoxia-inducible factor induces local thyroid hormone inactivation during hypoxic-ischemic disease in rats. $J$ Clin Invest 118: 975-983, 2008.

SNOJ-CVETKO E, SKETELJ J, DOLENC I, OBREZA S, JANMOT C, D’ALBIS A, ERŽEN I: Regenerated rat fast muscle transplanted to the slow muscle bed and innervated by the slow nerve, exhibits an identical myosin heavy chain repertoire to that of the slow muscle. Histochem Cell Biol 106: 473-479, $1996 \mathrm{a}$.

SNOJ-CVETKO E, SMERDU V, SKETELJ J, DOLENC I, D'ALBIS A, JANMOT C, ERŽEN I: Adaptive range of myosin heavy chain expression in regenerating soleus is broader than in mature muscle. $J$ Muscle Res Cell Motil 17: 401-409, 1996b.

SMERDU V, SOUKUP T: Demonstration of myosin heavy chain isoforms in rat and humans: the specificity of seven available monoclonal antibodies used in immunohistochemical and immunoblotting methods. Eur J Histochem 52: 179-190, 2008. 
SOUKUP T, JIRMANOVÁ I: Regulation of myosin expression in developing and regenerating extrafusal and intrafusal muscle fibers with special emphasis on the role of thyroid hormones. Physiol Res 49: 617-633, 2000.

SOUKUP T, ZURMANOVA J: How much do MyHC isoform mRNA levels correlate with MyHC protein levels and fiber type composition? J Muscle Res Cell Motil 33: 261, 2012.

SOUKUP T, ZACHAROVA G, SMERDU V, JIRMANOVÁ I: Body, heart, thyroid gland and skeletal muscle weight changes in rats with altered thyroid status. Physiol Res 50: 619-626, 2001.

SOUKUP T, ZACHAROVA G, SMERDU V: Fibre type composition of soleus and extensor digitorum longus muscles in normal female inbred Lewis rats. Acta Histochem 104: 399-405, 2002.

SOUKUP T, SMERDU V, ZACHAROVA G: Fiber type composition of unoperated rat soleus and extensor digitorum longus muscles after unilateral isotransplantation of a foreign muscle in long-term experiments. Physiol Res 58: 253-262, 2009.

SOUKUP T, SULIMENKO V, MARKOVÁ V, KOPECKÁ K, ZACHAŘOVÁ G, PALEČEK J: Expression of the skeletal calsequestrin isoform in normal and regenerated skeletal muscles and in hearts of rats with altered thyroid status. Physiol Res 61: 575-586, 2012.

SOUZA LL, CORDEIRO A, OLIVEIRA LS, DE PAULA GS, FAUSTINO LC, ORTIGA-CARVALHO TM, OLIVEIRA KJ, PAZOS-MOURA CC: Thyroid hormone contributes to the hypolipidemic effect of polyunsaturated fatty acids from fish oil: in vivo evidence for cross talking mechanisms. $J$ Endocrinol 211: 65-72, 2011.

SPANN J: Functional changes in pathologic hypertrophy. In: Growth of the Heart in Health and Disease. ZAK R (ed), Raven Press, New York, 1984, pp 421-466.

STEVENS L, SULTAN KR, PEUKER H, GOHLSCH B, MOUNIER Y, PETTE D: Changes in myosin heavy chain mRNA and protein isoforms in single fibers of unloaded rat soleus muscle. Am J Physiol 277: C1044-C1049, 1999.

STEVENSON LW: Beta-blockers for stable heart failure. N Engl J Med 346: 1346-1347, 2002.

SUGIYAMA E, ISHIKAWA Y, LI Y, KAGAI T, NOBAYASHI M, TANAKA N, KAMIJO Y, YOKOYAMA S, HARA A, AOYAMA T: Eicosapentaenoic acid lowers plasma and liver cholesterol levels in the presence of peroxisome proliferators-activated receptor alpha. Life Sci 83: 19-28, 2008.

SWYNGHEDAUW B: Developmental and functional adaptations of contractile proteins in cardiac and skeletal muscles. Physiol Rev 66: 710-771, 1986.

TOMELLERI G, PALMUCCI L, TONIN P, MONGINI T, MARINI M, L'ERARIO R, RIZZUTO N, VATTEMI G: SERCA1 and calsequestrin storage myopathy: a new surplus protein myopathy. Brain 129: 2085-2092, 2006.

TRIBULOVÁ N, OKRUHLICOVÁ L, VARON D, MANOACH M, PECHAŇOVÁ O, BERNÁTOVÁ I, WEISMANN P, BARANČÍK M, STYK J, SLEZÁK J: Structural substrates involved in the development of severe arrhythmias in hypertensive rat and aged guinea pig hearts. In: Cardiac Remodeling and Failure. NS DHALLA, P SINGAL (eds), Kluwer Academic Publishers, Boston, 2002, pp 377-398.

TRIBULOVÁ N, DUPONT E, SOUKUP T, OKRUHLICOVÁ L, SEVERS NJ: Sex differences in connexin-43 expression in left ventricles of aging rats. Physiol Res 54: 705-708, 2005.

TRIBULOVÁ N, KNEZL V, OKRUHLICOVA L, SLEZAK J: Myocardial gap junctions: targets for novel approaches in the prevention of life-threatening cardiac arrhythmias. Physiol Res 57 (Suppl 2): S1-S13, 2008.

TRIBULOVÁ N, KNEZL V, SHAINBERG A, SEKI S, SOUKUP T: Thyroid hormones and cardiac arrhythmias. Vascul Pharmacol 52: 102-112, 2010.

VADÁSZOVÁ-SOUKUP A, SOUKUP T: Dual role of thyroid hormones in rat soleus muscle MyHC isoform expression. Physiol Res 56: 833-836, 2007.

VADÁSZOVÁ A, ZACHAROVA G, MACHÁČOVÁ K, JIRMANOVÁ I, SOUKUP T: Influence of thyroid status on the differentiation of slow and fast muscle phenotypes. Physiol Res $\mathbf{5 3}$ (Suppl 1): S57-S61, 2004.

VADÁSZOVÁ A, HUDECOVÁ S, KRIŽANOVÁ O, SOUKUP T: Levels of myosin heavy chain mRNA transcripts and content of protein isoforms in the slow soleus muscle of 7-month-old rats with altered thyroid status. Physiol Res 55: 221-225, 2006a. 
VADÁSZOVÁ A, HUDECOVÁ S, KRIŽANOVÁ O, SOUKUP T: Levels of myosin heavy chain mRNA transcripts and protein isoforms in the fast extensor digitorum longus muscle of 7-month-old rats with chronic thyroid status alterations. Physiol Res 55: 707-710, 2006b.

VENDITTI P, DI MEO S: Thyroid hormone-induced oxidative stress. CMLS 63: 414-434, 2006.

VISIOLI F, GIORDANO E, NICOD NM, DÁVALOS A: Molecular targets of omega-3 and conjugated linoleic fatty acids- ,, micromanaging“" cellular response. Front Physiol 3: Article 42, 2012.

VON SCHACKY C: Omega-3 index and sudden cardiac death. Nutrients 2: 375-388, 2010.

VON SCHACKY C: Omega-3 fatty acids: anti-arrhythmic, pro-arrhythmic, or both? Front Physiol 3: Article 88, 2012.

WALLIMANN T, TOKARSKA-SCHLATTNER M, SCHLATTNER U: The creatine kinase system and pleiotropic effects of creatine. Amino Acids 40: 1271-1296, 2011.

WANG PY, CHEN JJ, SU HM: Docosahexaenoic acid supplementation of primary rat hippocampal neurons attenuates the neurotoxicity induced by aggregated amyloid beta protein (42) and up-regulates cytoskeletal protein expression. J Nutr Biochem 21: 345-50, 2010.

WASKOVA-ARNOSTOVA P, ELSNICOVA B, KASPAROVA D, SEBESTA O, NOVOTNY J, NECKAR J, KOLAR F, ZURMANOVA J: Right-to-left ventricular differences in the expression of mitochondrial hexokinase and phosphorylation of Akt. Cell Physiol Biochem 31: 66-79, 2013.

WEI L, HANNA AD, BEARD NA, DULHUNTY AF: Unique isoform-specific properties of calsequestrin in the heart and skeletal muscle. Cell Calcium 45: 474-484, 2009.

WEITZEL JM, IWEN KA: Coordination of mitochondrial biogenesis by thyroid hormone. Mol Cell Endocrinol 342: $1-7,2011$.

WILCOXON JS, NADOLSKI GJ, SAMARUT J, CHASSANDE O, REDEI EE: Behavioral inhibition and impaired spatial learning and memory in hypothyroid mice lacking thyroid hormone receptor alpha. Behav Brain Res 177: 109-116, 2007.

WU MF, LI PC, CHEN CC, YE SS, CHIEN CT, YU CC: Cordyceps sobolifera extract ameliorates lipopolysaccharideinduced renal dysfunction in the rat. Am J Chin Med 39: 523-35, 2011.

YEN PM: Physiological and molecular basis of thyroid hormone action. Physiol Rev 81: 1097-1142, 2001.

YOULE RJ, STRASSER A: The BCL-2 protein family: opposing activities that mediate cell death. Nat Rev Mol Cell Biol 9: 47-59, 2008.

ZACHAROVA G, VADÁSZOVÁ A, SMERDU V, ASMUSSEN G, SOUKUP T: The effect of a unilateral muscle transplantation on the muscle fiber type and the MyHC isoform content in unoperated hind limb slow and fast muscles of the inbred Lewis rats. Physiol Res 54: 691-696, 2005.

ZHANG Z, WANG H, JIAO R, PENG C, WONG YM, YEUNG VS, HUANG Y, CHEN ZY: Choosing hamster but not rats as a model for studying plasma cholesterol-lowering activity of functional foods. Mol Nutr Food Res 53: 921-930, 2009.

ZURMANOVA J, SOUKUP T: Comparison of myosin heavy chain mRNAs, protein isoforms and fiber type proportions in the rat slow and fast muscles. Physiol Res 62: 445-453, 2013.

ZURMANOVA J, MALACOVA D, PUTA F, NOVÁK P, ŘíČNÝ J, SOUKUP T: Mass spectrometry analyses of rat 2b myosin heavy chain isoform. Physiol Res 56: 659-662, 2007.

ZURMANOVA J, PUTA F, STOPKOVA R, SOUKUP T: Real time RT-PCR with newly designed primers confirmed the presence of $2 \mathrm{~b}$ and $2 \mathrm{x} / \mathrm{d}$ myosin heavy chain mRNAs in the rat slow soleus muscle. Physiol Res 57: 973-978, 2008. 